\title{
Intramuscular injection safety without aspiration in the ventro- gluteal region during vaccination: randomized clinical trial
}

Segurança da injeção intramuscular sem aspiração na região ventro-glútea durante a vacinação: ensaio clínico randomizado

Seguridad de la inyección intramuscular sin aspiración en la región ventroglútea durante la vacunación: ensayo clínico aleatorizado

\section{Alanna Michella Oliveira de Albuquerque da Silva' ORCID: 0000-0002-7318-941X \\ Regina Célia Sales Santos' ORCID: 0000-0002-2447-0707 \\ Maria Gabriella Silva Araujo' ORCID: 0000-0003-0495-3362 \\ Lucas Henrique Lopes Silva' ORCID: 0000-0002-5494-204X \\ Diane Fernandes dos Santos' ORCID: 0000-0002-5472-4122}

'Universidade Federal de Alagoas. Maceió, Alagoas, Brazil.

How to cite this article:

Silva AMOA, Santos RCS, Araujo MGS, Silva LHL, Santos DF. Safety of intramuscular injection without aspiration in the ventro-gluteal region during vaccination: randomized clinical trial. Rev Bras Enferm. 2022;75(1):e20201119.

https://doi.org/10.1590/0034-7167-2020-1119

Corresponding author:

Regina Célia Sales Santos

E-mail: reginasales@eenf.ufal.br

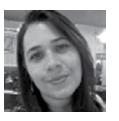

EDITOR IN CHIEF: Antonio José de Almeida Filho ASSOCIATE EDITOR: Álvaro Sousa

Submission: 11-07-2020

Approval: 03-29-2021

\begin{abstract}
Objectives: to compare adverse events after administrating hepatitis A vaccine intramuscularly in the ventro-gluteal region between techniques with and without aspiration. Methods: randomized double-blind clinical trial, using hepatitis A vaccine (inactivated) in the ventro-gluteal region, with a sample of 74 participants in the intervention group, vaccinated with the slow injection technique without aspiration, and 74 participants in the control group undergoing slow injection with aspiration. Daily assessment of participants was carried out in the 72 hours after vaccination, in order to ascertain local, systemic adverse events, local and contralateral temperatures. Results: the occurrence of local and systemic adverse events was homogeneous between the groups in the three days after vaccination ( $p>0.05$ ). There was no influence of sex, race, pre-existing disease and use of medication. Conclusions: the intramuscular vaccination technique without aspiration in the ventro-gluteal region is safe for adverse events following immunization compared to the conventional technique with aspiration.

Descriptors: Injections, Intramuscular; Vaccination; Injection Site Reaction; Randomized Controlled Trial; Evidence-Based Nursing.
\end{abstract}

\section{RESUMO}

Objetivos: comparar os eventos adversos após a administração da vacina hepatite $A$ via intramuscular na região ventro-glútea entre as técnicas com e sem aspiração. Métodos: ensaio clínico randomizado duplo-cego, utilizando a vacina hepatite $A$ (inativada) na região ventro-glútea, com amostra de 74 participantes no grupo intervenção, vacinados com a técnica de injeção lenta sem aspiração, e 74 participantes no grupo controle submetidos à injeção lenta com aspiração. Foi realizada avaliação diária dos participantes nas 72 horas pós-vacinação, com intuito de averiguar eventos adversos locais, sistêmicos, temperaturas locais e contralaterais. Resultados: a ocorrência de eventos adversos locais e sistêmicos foi homogênea entre os grupos nos três dias pós-vacinação $(p>0,05)$. Não houve influência das variáveis sexo, raça, doença pré-existente e uso de medicamento. Conclusões: a técnica de vacinação intramuscular sem aspiração na região ventro-glútea é segura quanto aos eventos adversos pós-vacinação em comparação à técnica convencional com aspiração.

Descritores: Injeções Intramusculares; Vacinação; Efeito Adverso no Local de Injeção; Ensaio Clínico Controlado Randomizado; Enfermagem Baseada em Evidências.

\section{RESUMEN}

Objetivos: comparar eventos adversos después de la administración de la vacuna contra la hepatitis A por vía intramuscular en la región ventroglútea entre técnicas con y sin aspiración. Métodos: ensayo clínico aleatorizado doble ciego utilizando la vacuna Hepatitis A (inactivada) en la región ventroglútea, con una muestra de 74 participantes en el grupo de intervención, vacunados con la técnica de inyección lenta sin aspiración, y 74 participantes del grupo control sometidos a inyección con aspiración. La evaluación diaria de los participantes se llevó a cabo en las 72 horas posteriores a la vacunación, con el fin de conocer los eventos adversos locales, sistémicos, las temperaturas locales y contralaterales. Resultados: la ocurrencia de eventos adversos locales y sistémicos fue homogénea entre los grupos en los tres días posteriores a la vacunación ( $p>0.05$ ). No hubo influencia de las variables sexo, raza, enfermedad preexistente y uso de medicación. Conclusión: la técnica de vacunación intramuscular sin aspiración en la región ventroglútea es segura para eventos adversos después de la vacunación en comparación con la técnica convencional con aspiración. Descriptores: Inyecciones Intramusculares; Vacunación; Reacción en el Punto de Inyección; Ensayo Clínico Controlado Aleatorio; Enfermería Basada en la Evidencia. 


\section{INTRODUCTION}

Aspiration in intramuscular injection (IM) consists of a technique performed in order to avoid inadvertent inoculation of a vaccine or medication directly into the bloodstream, however there is no evidence to justify its use. Furthermore, results of studies indicate higher levels of pain due to movement and the longer time the needle remains in tissues with aspiration ${ }^{(1)}$.

Recommended sites for vaccine administration do not have large blood vessels and there are no studies reporting any damage from non-aspiration prior to vaccination ${ }^{(1)}$. However, nursing professionals can establish barriers to this technique, as they feel afraid to cause any adverse event in the vaccinated individual(2).

Thus, to change in the service practice, it is essential that the techniques implemented have proven safety and efficacy so that they are not associated with the occurrence of adverse events following immunization (AEFI), one of the main reasons for refusal or vaccination hesitation, even if self-limited and mild in comparison to the morbidity and mortality of diseases avoided ${ }^{(3)}$

AEFIs can be caused by one or more vaccines administered or only temporarily associated with vaccination. These are expected and unexpected reactions that vary according to the vaccinated individuals' response, effects of the vaccine administered or resulting from professional error in the reconstitution, preparation or administration of an immunobiological agent ${ }^{(4)}$.

Proof of low reactogenicity and vaccination safety, combined with the use of methods that reduce the pain caused by sequential injections, can reduce individuals' apprehension and motivate the return to the health service to continue the vaccination schedule, with a positive impact on vaccination coverage and prevention of vaccine-preventable diseases ${ }^{(5)}$.

Therefore, considering that the IM route is indicated for most immunobiological agents and the absence of studies on injection without aspiration during vaccination in the ventro-gluteal region (VG), it is pertinent to ask: is non-aspiration prior to hepatitis A vaccine administration via IM in the VG region safe compared to AEFI compared to the standard aspiration technique? In the perspective of testing the hypothesis $(\mathrm{H} 0)$ of the technique without aspiration, to present similar adverse events in comparison to the conventional technique with aspiration, and, alternatively $(\mathrm{H} 1)$, of the non-aspiration technique, to present a reduction in AEFIs in relation to the conventional technique.

\section{OBJECTIVE}

To compare adverse events after administrating hepatitis $A$ vaccine intramuscularly in the ventro-gluteal region between techniques with and without aspiration.

\section{METHODS}

\section{Ethical aspects}

The clinical trial met the ethical recommendations regarding research with human beings, obtaining approval from the Institutional Review Board of Universidade Federal de Alagoas and from the Brazilian Clinical Trial Registry, with Protocol RBR-8nkhhk. Participants confirmed their participation by reading and signing the Informed Consent Form (ICF).

\section{Study design, place and period}

This is a randomized clinical trial (RCT) guided by the CONSORT tool, double-blind, parallel, two-arm, with pain, AEFI and immunogenicity as outcomes; however, in this article, AEFIs were evaluated between IM injection techniques without aspiration and with aspiration after hepatitis $A$ vaccine administration (inactivated) in the VG region. Hepatitis $A$ vaccine was selected for this study in order to decrease the loss of participants due to previous vaccination against the disease, since this vaccine is available in the public network only for people aged between one and four years or within the guidelines of the Reference Centers for Special Immunobiological agents (CRIE - Centros de Referência para Imunobiológicos Especiais) (6). The study was carried out in a food industry in Maceió, Alagoas, Brazil, conducted from May 2019 to August 2020.

\section{Population and sample}

The research subjects were adults from 18 to 59 years old. Individuals with immunosuppressive disease or treatment, acute febrile illness, use of anti-inflammatory, analgesic or antipyretic medication 24 hours before vaccination, history of allergic reaction to any of the hepatitis A vaccine components, pregnancy, history of hepatitis $A$ disease, history of hepatitis A vaccine, people who have had a blood transfusion or use of blood products in the last 28 days, people who are unable to answer for themselves were excluded.

The sample size was calculated based on another clinical trial ${ }^{(7)}$, considering a difference detected in the population of 5 beats per minute (bpm), standard deviation of $12 \mathrm{bpm}$, significance level of $5 \%$ and single-tailed test power of $80 \%$. One-tailed test power was considered, because, according to the hypotheses described, the effects go in only one possible direction. Heart rate (HR) was used to calculate the sample, as the study also analyzed the response to pain, with the vaccination procedure between the groups, using HR values, peripheral oxygen saturation and the numerical intensity scale pain, treated in another article. Thus, 148 individuals participated in the study, 74 in the intervention group (IG) and 74 in the control group (CG).

\section{Study protocol}

Recruitment took place during an educational health lecture in the workplace. Subsequently, the inclusion, exclusion criteria and conditions that indicated the postponement or contraindication of vaccination were investigated. Participants were informed about the objective, procedures, risks and benefits of the study and signed a participation agreement signing the ICF.

Subject allocation to the groups was carried out through randomization in the online program Sealed Envelope, with Protocol 108762370579537, in blocks of four envelopes, for which 200 opaque sealed envelopes were made containing an external code and, inside, the name of participants in the allocation group: Slow injection group with aspiration or Slow injection group without aspiration. The preparation of the envelopes was carried out by employees who did not participate in data collection, aiming to minimize selection bias.

When selecting a sealed envelope for participants, the external code was noted on the data collection instrument and completed identification data and health information. Then, participants were 
referred for vaccination and only the main researcher (responsible for administering the vaccine) broke the seal and had access to information about the group in which it was allocated. Participants and team members who performed AEFI assessment and statistical analysis did not know which group participants belonged to, nor did the researcher who performed the intervention not witness the AEFI assessment.

The VG region site was performed according to the geometric delimitation method, which consists of drawing imaginary lines between the antero-superior iliac crest, the posterior margin of the iliac tubercle and the greater trochanter of the femur, whose union of the vertices will form a triangle and its barycenter indicates the puncture site ${ }^{(8)}$.

A single batch of the purified and inactivated adult anti-hepatitis $A$ vaccine (VAQTA) was used (N020054) in the single dose presentation $(1 \mathrm{~mL})$, consisting of $50 \mathrm{U}$ of the hepatitis $A$ virus antigen per $\mathrm{mL}$, in addition to aluminum hydroxyphosphate sulfate amorphous, sodium borate, sodium chloride and water for injections. The vaccine was administered via IM in the right or left VG region, with a $5 \mathrm{~mL}$ syringe and $25 \times 0.7 \mathrm{~mm}$ gauge needle, inserted at an angle of $90^{\circ}$ in relation to the skin and bevel positioned laterally in the direction of the local muscle fibers. The same needle used to aspirate the vaccine dose was used for application. Vaccination was filmed for approximately one minute. After that, each participant was instructed on possible adverse reactions, care for symptom relief and return, for assessment for three consecutive days.

Day zero (D0) was considered the day of vaccination and, later, day one (D1), day two (D2) and day three (D3), in which participants were interviewed and evaluated to check for the presence of local manifestations (pain, induration, flushing, heat, edema, nodule, abscess) and systemic (fever, fatigue, headache, irritability, nausea, vomiting, diarrhea, abdominal pain, muscle pain, lack of appetite) ${ }^{(9)}$. On each evaluation day, the temperatures of the vaccine application site and the contralateral region were measured with an infrared pyrometer thermometer from $+30^{\circ} \mathrm{C}$ to $+550^{\circ} \mathrm{C}$, adjustable, portable emissivity, positioned at a minimum distance of $30 \mathrm{~cm}$ from the application site, as instructed in the technical manual, and away from the flow of air conditioning and heat sources.

Then, a photographic record of the injection region was performed, identified by the participant's initials, with a camera positioned on a universal tripod. The application site was inspected and palpated for pain, nodules and induration, the latter measured with a disposable ruler graduated in centimeters $(\mathrm{cm})$ and millimeters ( $\mathrm{mm}$ ). Participants who were absent from the workplace during the assessment period were assessed at their homes. The research team provided guidance to those who presented AEFI, with follow-up until the signs and symptoms disappeared.

\section{Analysis of results, and statistics}

Quantitative analysis was performed by storing the data in the statistical package SPSS (Statistical Package for Social Sciences), version 21.0.0.0. In the descriptive statistical analysis, absolute and percentage frequency, mean, standard deviation (SD) and standard error of the mean (SEM) were calculated. For inferential analysis, group characterization data (age, sex, race, pre-existing disease and use of medication), adverse events, use of post-vaccination intervention and temperatures were analyzed.

The Kolmogorov-Smirnov test was used to verify the normal distribution of the variables of age and temperature. Pearson's chi-square test was used to compare sex, race, pre-existing disease, medication use, local and systemic adverse events between groups. Mann-Whitney and Student's t tests were used to evaluate the temperature variable. The research adopted a $95 \%$ confidence interval and a $5 \%$ significance level $(p<0.05)$. The data were presented in tables and discussed according to literature.

\section{RESULTS}

Recruitment took place from September 2019 to March 2020. 148 individuals participated in the research, 74 in IG and 74 in CG, allocated according to the CONSORT flowchart below:

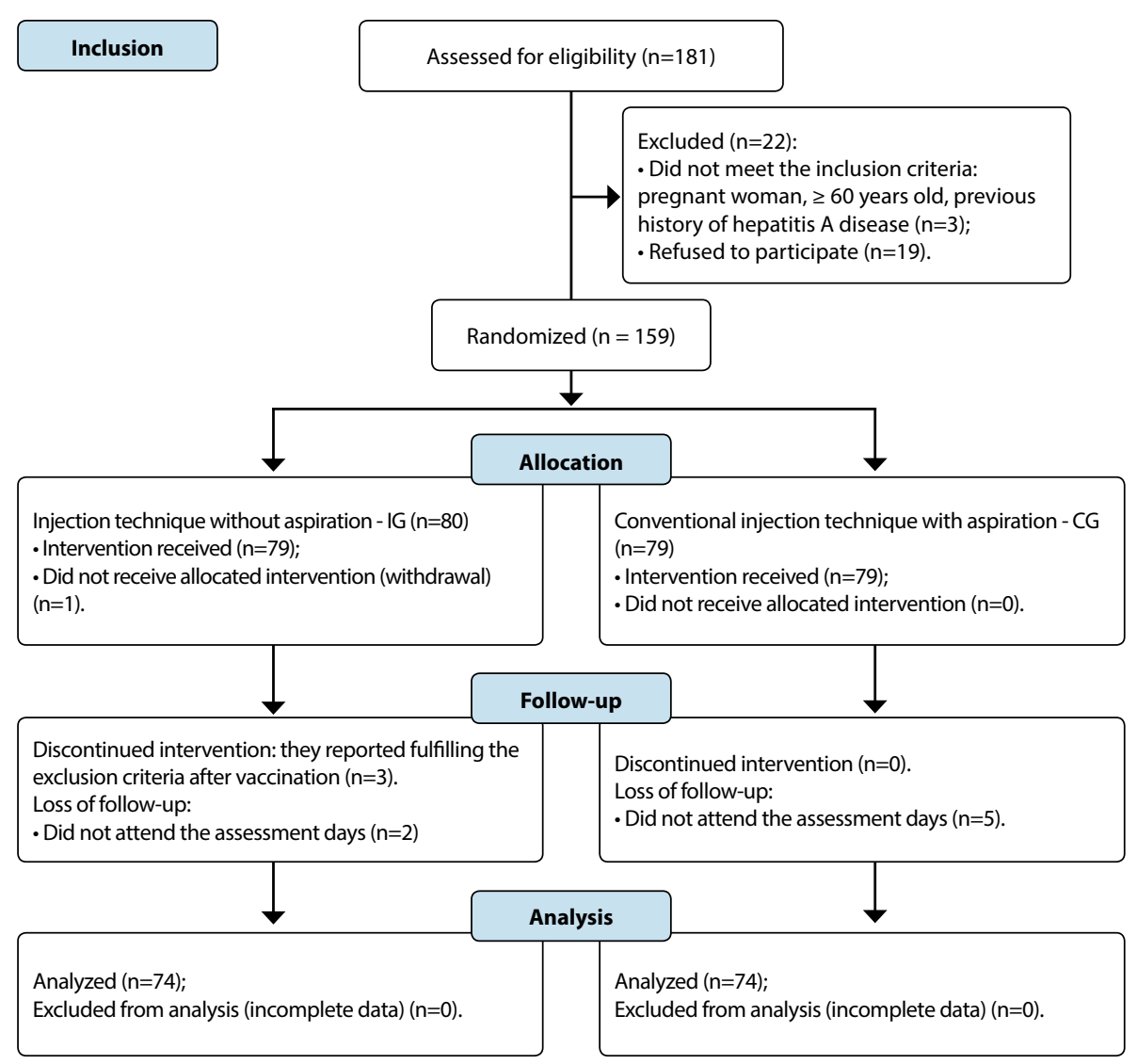

Figure 1 - Research flowchart based on the CONSORT model, Maceió, Alagoas, Brazil, 2020 
Study participants were aged between 18 and 59 years, with a mean of 38.31 years of age (SD \pm 10.57 ), with no significant differences between IG and CG ( $p=0.496)$, with a mean of 38.90 years (SD \pm 11.03 ) in IG and 37.71 years $(S D \pm 10.14)$ in $C G$.

According to Table 1, most participants were male and selfdeclared brown in both groups. In addition, most reported not having a pre-existing disease or using any medication during the vaccination period. However, these differences were not significant between groups ( $p>0.05)$.

Table 1 - Characterization of the intervention and control groups regarding sex, race, pre-existing condition and use of medication, Maceió, Alagoas, Brazil, 2020

\begin{tabular}{|c|c|c|c|c|c|}
\hline \multirow[b]{2}{*}{ Variable } & \multicolumn{2}{|c|}{ Group } & \multirow[b]{2}{*}{$\underset{\text { value }}{p}$} & \multirow[b]{2}{*}{$\mathbf{O R}^{*}$} & \multirow[b]{2}{*}{$95 \%{ }^{+} \mathrm{Cl}$} \\
\hline & $\begin{array}{c}\text { Intervention } \\
(\mathbf{n}=74) \\
n(\%)\end{array}$ & $\begin{array}{c}\text { Control } \\
(n=74) \\
n(\%)\end{array}$ & & & \\
\hline \multicolumn{6}{|l|}{ Sex } \\
\hline Female & 25 (16.9) & $21(14.2)$ & $0.594^{\ddagger}$ & 1.28 & $0.64-2.58$ \\
\hline Male & $49(33.1)$ & $53(35.8)$ & & & \\
\hline \multicolumn{6}{|l|}{ Race } \\
\hline Yellow & $2(1.4)$ & $4(2.7)$ & & & \\
\hline White & $14(9.5)$ & $9(6.1)$ & $0.066^{\ddagger}$ & - & - \\
\hline Indigenous & $1(0.7)$ & $2(1.4)$ & & & \\
\hline Brown & $51(34.5)$ & $42(28.4)$ & & & \\
\hline Black & $6(4.1)$ & $17(11.5)$ & & & \\
\hline \multicolumn{6}{|c|}{ Pre-existing condition } \\
\hline Yes & $19(12.8)$ & $22(14.9)$ & $0.714^{\ddagger}$ & 1.22 & $0.59-2.52$ \\
\hline No & $55(37.2)$ & $52(35.1)$ & & & \\
\hline \multicolumn{6}{|c|}{ Use of medication } \\
\hline Yes & $21(14.2)$ & $20(13.5)$ & $0.714^{\ddagger}$ & 0.81 & $0.39-1.68$ \\
\hline No & $52(35.1)$ & $55(37.2)$ & & & \\
\hline
\end{tabular}

Note: *OR - Odds Ratio; $+C l$ - confidence interval; $¥$ Pearson's chi-square test.

Regarding local manifestations and adjacent to the injection site, according to Table 2, there was no case of nodulation. Flushing cases were more frequent in people belonging to CG (aspiration technique), with a greater difference between the groups on the second day, 26 people (17.6\%) from CG, but without significance $(p=0.100)$. Flushing cases had a larger size on day $1(n=66)$, with a mean of $0.15 \mathrm{~cm}(\mathrm{SD} \pm 0.07)$, a maximum of $0.5 \mathrm{~cm}$ and a minimum of $0.1 \mathrm{~cm}$, decreased on day $2(\mathrm{n}=42)$ for a mean of $0.11 \mathrm{~cm}$ $(\mathrm{SD} \pm 0.05)$, a maximum of $0.4 \mathrm{~cm}$ and a minimum of $0.1 \mathrm{~cm}$ and, again, lower on day $3(n=15)$, with a mean size of $0.11 \mathrm{~cm}(S D \pm$ 0.03 ), maximum $0.2 \mathrm{~cm}$ and minimum $0.1 \mathrm{~cm}$. Often, they were circumscribed to the edge of the injection site.

The occurrences of pain at the injection site and hematoma were approximate between the groups, with no significant differences ( $p>0.05)$. Participants who had a hematoma did not previously report use of anticoagulant or antiplatelet medication. It is worth noting the absence of blood return in the syringe in the procedures in which the aspiration was performed.

Regarding other manifestations adjacent to the injection site, there were cases of cramp, muscle fatigue, paresthesia (tingling or numbness) and leg pain, with no significant differences between the intervention and control groups ( $p>0.05)$.

Local manifestations occurred homogeneously between groups ( $p>0.05$ ) and were not influenced by the injection technique with or without aspiration.

In Table 3, it is observed in the data related to systemic manifestations, that the most referred symptom was headache, presented by five people on day 1 (3.4\%), by six people (4.1\%) on day 2 and by three people $(2.1 \%)$ on day 3 , after vaccination and, in some cases, it was associated with another symptom, such as myalgia, vertigo and sore throat.

Table 2 - Manifestations local and adjacent to the injection site presented by intervention and control group participants until the third day after hepatitis A vaccination, Maceió, Alagoas, Brazil, 2020

\begin{tabular}{|c|c|c|c|c|c|}
\hline & Group & & & & \\
\hline Manifestation & $\begin{array}{c}\text { Intervention } \\
(n=74) \\
n(\%)\end{array}$ & $\begin{array}{c}\text { Control } \\
(n=74) \\
n(\%)\end{array}$ & $\begin{array}{c}p \\
\text { value }\end{array}$ & $\mathbf{O R}^{*}$ & $95 \%{ }^{+} \mathrm{Cl}$ \\
\hline Flush D1 $1^{*}$ & & & & 1.24 & $0.65-2.38$ \\
\hline With manifestation & $31(20.9)$ & $35(23.6)$ & $0.620^{\S}$ & & \\
\hline Without manifestation & $43(29.1)$ & $39(26.4)$ & & & \\
\hline Flush D2\| & & & & 1.96 & $0.94-4.07$ \\
\hline With manifestation & $16(10.8)$ & $26(17.6)$ & $0.100^{\S}$ & & \\
\hline Without manifestation & $58(39.2)$ & $48(32.4)$ & & & \\
\hline Flush D3" & & & & 1.16 & $0.39-3.38$ \\
\hline With manifestation & $7(4.7)$ & $8(5.4)$ & $1.00^{\S}$ & & \\
\hline Without manifestation & $67(45.3)$ & $66(44.6)$ & & & \\
\hline Local pain $\mathrm{D} 1$ ₹ & & & & 0.90 & $0.37-2.19$ \\
\hline With manifestation & $12(8.1)$ & $11(7.4)$ & $1.00^{\S}$ & & \\
\hline Without manifestation & $62(41.9)$ & $63(42.6)$ & & & \\
\hline Local pain D2\| & & & & 1.71 & $0.39-7.45$ \\
\hline With manifestation & $3(2.0)$ & $5(3.4)$ & $0.719^{\S}$ & & \\
\hline Without manifestation & $71(48)$ & $69(46.6)$ & & & \\
\hline Local pain D3" & & & & 0.32 & $0.03-3.19$ \\
\hline With manifestation & $3(2.0)$ & $1(0.7)$ & $0.620^{\S}$ & & \\
\hline Without manifestation & $71(48)$ & $73(49.3)$ & & & \\
\hline Hematoma D1 * & & & & 1.52 & $0.24-9.37$ \\
\hline With manifestation & $2(1.4)$ & $3(2.0)$ & $1.00^{\S}$ & & \\
\hline Without manifestation & $72(48.6)$ & $71(48.0)$ & & & \\
\hline Hematoma D2\| & & & & 2.08 & $0.50-8.68$ \\
\hline With manifestation & $3(2.0)$ & $6(4.1)$ & $0.494^{\S}$ & & \\
\hline Without manifestation & $71(48)$ & $68(45.9)$ & & & \\
\hline Hematoma D3" & & & & 2.08 & $0.50-8.68$ \\
\hline With manifestation & $3(2.0)$ & $6(4.1)$ & $0.494^{\S}$ & & \\
\hline Without manifestation & $71(48)$ & $68(45.9)$ & & & \\
\hline Other manifestations $\mathrm{D} 1^{*}$ & & & $0.497^{\S}$ & - & \\
\hline Fatigue & $0(0.0)$ & $1(0.7)$ & & & \\
\hline Paresthesia & $0(0.0)$ & $1(0.7)$ & & & \\
\hline Without manifestation & $74(50)$ & $72(48.6)$ & & & \\
\hline Other manifestations D2\| & & & & & \\
\hline Cramp & $1(0.7)$ & $0(0.0)$ & & - & - \\
\hline Leg pain & $0(0.0)$ & $1(0.7)$ & $1.00^{5}$ & & \\
\hline Without manifestation & $73(49.3)$ & $73(49.3)$ & & & \\
\hline Other manifestations D3" & & & & 2.01 & $1.71-2.37$ \\
\hline Cramp & $1(0.7)$ & $0(0.0)$ & $1.00^{5}$ & & \\
\hline Without manifestation & $73(49.3)$ & $74(50)$ & & & \\
\hline
\end{tabular}

Note: *OR - Odds Ratio; $+C l$ - confidence interval; §Pearson's chi-square test; $\neq D 1$ - day 1; $\| D 2$ - day 2; $9 D 3$ - day 3.

Furthermore, other manifestations have been reported, such as fatigue, fever, nausea, drowsiness, gastrointestinal disorders (colic and diarrhea) and chills. It is important to note the absence of severe $\mathrm{AEFI}$ and post-vaccination anaphylactic reaction.

CG presented more systemic adverse events in relation to IG on the first and second post-vaccination days, with the exception of the third day, in which IG reported more adverse events than CG, as shown in Table 3, but there was no statistical significance in any of days ( $p>0.05$ ), indicating that IM injection technique with or without aspiration was not related to the appearance of adverse events. 
Table 3 - Systemic manifestations presented by intervention and control group participants until the third day after hepatitis A vaccination, Maceió, Alagoas, Brazil, 2020

\begin{tabular}{|c|c|c|c|}
\hline \multirow[b]{2}{*}{ Manifestation } & \multicolumn{2}{|c|}{ Group } & \multirow[b]{2}{*}{$\begin{array}{c}p \\
\text { value }\end{array}$} \\
\hline & $\begin{array}{c}\text { Intervention } \\
(\mathrm{n}=74) \\
n(\%)\end{array}$ & $\begin{array}{c}\text { Control } \\
(n=74) \\
n(\%)\end{array}$ & \\
\hline $\mathrm{D} 1$ * & & & 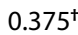 \\
\hline Chronic headache & $2(1.4)$ & $3(2.0)$ & \\
\hline Fatigue & $2(1.4)$ & $1(0.7)$ & \\
\hline Fever & $0(0.0)$ & $1(0.7)$ & \\
\hline Nausea & $0(0.0)$ & $2(1.4)$ & \\
\hline Drowsiness & $0(0.0)$ & $2(1.4)$ & \\
\hline Without manifestation & $70(47.3)$ & $65(43.9)$ & \\
\hline $\mathrm{D} 2^{\ddagger}$ & & & $0.197^{\dagger}$ \\
\hline Chronic headache & $1(0.7)$ & $4(2.7)$ & \\
\hline Chronic headache and vertigo & $0(0.0)$ & $1(0.7)$ & \\
\hline Fatigue & $1(0.7)$ & $1(0.7)$ & \\
\hline Diarrhea & $1(0.7)$ & $0(0.0)$ & \\
\hline Myalgia & $0(0.0)$ & $1(0.7)$ & \\
\hline Shivering & $1(0.7)$ & $0(0.0)$ & \\
\hline Without manifestation & $74(50.0)$ & $67(45.3)$ & \\
\hline $\mathrm{D} 3^{\S}$ & & & $1.00^{+}$ \\
\hline Chronic headache & $1(0.7)$ & $1(0.7)$ & \\
\hline Chronic headache, myalgia and sore throat & $1(0.7)$ & $0(0.0)$ & \\
\hline Cramps & $1(0.7)$ & $0(0.0)$ & \\
\hline Nausea & $0(0.0)$ & $1(0.7)$ & \\
\hline Myalgia & $0(0.0)$ & $1(0.7)$ & \\
\hline Shivering & $1(0.7)$ & $0(0.0)$ & \\
\hline Without manifestation & $70(47.3)$ & $71(48.0)$ & \\
\hline
\end{tabular}

When analyzing the duration of the adverse events presented, the local manifestations had a mean duration of 46.15 hours (SD \pm 55.89 ) after vaccination, a minimum of 0.02 hours (one minute) and a maximum of 216 hours (nine days). The hematoma was AEFI with the longest stay. Regarding systemic manifestations, the mean duration was 11 hours, maximum 48 hours and minimum half an hour (30 minutes).

Table 4 - Local and contralateral temperature of the ventro-gluteal region in the intervention and control groups up to 72 hours after hepatitis A vaccination, Maceió, Alagoas, Brazil, 2020.

\begin{tabular}{|c|c|c|c|c|c|}
\hline \multirow[b]{2}{*}{ Variable } & \multicolumn{5}{|c|}{ Temperature } \\
\hline & $\mathbf{N}$ & Mean ( \pm SD*) & \pm SEM $^{\dagger}$ & $\begin{array}{l}\text { Minimum- } \\
\text { Maximum }\end{array}$ & $\begin{array}{c}p \\
\text { value }\end{array}$ \\
\hline Local temperature $\mathrm{D} 1^{\ddagger}$ & & & & & $0.145^{\S}$ \\
\hline Intervention & 74 & $31.64( \pm 1.89)$ & \pm 0.22 & $24.90-34.50$ & \\
\hline Control & 74 & $31.23( \pm 2.12)$ & \pm 0.24 & $23.60-35.50$ & \\
\hline Contralateral temperature $\mathrm{D} 1^{\ddagger}$ & & & & & $0.436^{\S}$ \\
\hline Intervention & 74 & $31.38( \pm 2.17)$ & \pm 0.25 & $25.90-35.10$ & \\
\hline Control & 74 & $31.03( \pm 2.33)$ & \pm 0.27 & $24.10-35.30$ & \\
\hline Local temperature D2\| & & & & & $0.044^{\S}$ \\
\hline Intervention & 74 & $31.82( \pm 1.96)$ & \pm 0.22 & $26.10-36.10$ & \\
\hline Control & 74 & $31.04( \pm 2.20)$ & \pm 0.25 & $25.80-34.60$ & \\
\hline Contralateral temperature D2\| & & & & & $0.671^{\pi}$ \\
\hline Intervention & 74 & $31.68( \pm 2.26)$ & \pm 0.26 & $25.60-35.40$ & \\
\hline Control & 74 & $31.51( \pm 2.48)$ & \pm 0.28 & $24.30-40.00$ & \\
\hline Local temperature D3** & & & & & $0.130^{\S}$ \\
\hline Intervention & 74 & $31.89( \pm 2.21)$ & \pm 0.25 & $24.30-35.90$ & \\
\hline Control & 74 & $31.28( \pm 2.50)$ & \pm 0.29 & $22.90-35.60$ & \\
\hline Contralateral temperature D3** & & & & & $0.982^{\S}$ \\
\hline Intervention & 74 & $31.72( \pm 2.10)$ & \pm 0.24 & $26.50-35.10$ & \\
\hline Control & 74 & $31.50( \pm 2.44)$ & \pm 0.28 & $24.70-34.90$ & \\
\hline
\end{tabular}

Note: *SD - standard deviation; +SEM - standard error of the mean; $\neq D 1$ - day $1 ; \| D 2$ - day 2; **D3 - day 3; §MannWhitney test; 9 Student's t-test.
When asked, few participants mentioned performing any intervention to relieve post-vaccination symptoms. Among the interventions performed, compresses were reported on D1 in the CG $(p=1.00)$ and use of vitamin and herbal tea in D3 in IG $(p=0.477)$.

Table 4 presents data on local and contralateral surface temperatures of the VG region, measured daily up to 72 hours after vaccination.

Mean temperatures were around $31^{\circ} \mathrm{C}$ in both groups. Furthermore, the IG means, both from the application site and from the opposite side, were higher in the three days of evaluation, with a significantly greater difference $(p=0.044)$ on the second day after vaccination at the local temperature of $I G\left(T=31.82^{\circ} \mathrm{C}\right)$ in relation to $C G\left(T=31.04^{\circ} \mathrm{C}\right)$.

There was a progressive increase in IG temperatures over 24 hours $\left(T=31.64^{\circ} \mathrm{C}\right), 48$ hours $\left(T=31.82^{\circ} \mathrm{C}\right)$ and 72 hours $\left(T=31.89^{\circ} \mathrm{C}\right)$ at the vaccine application site. Elevation was also accompanied by contralateral temperatures, which registered means of $31.38^{\circ} \mathrm{C}$ on the first day, $31.68^{\circ} \mathrm{C}$ on the second and $31.72^{\circ} \mathrm{C}$ on the third day. An analysis of the local temperatures of participants who had manifestations, such as flushing and local pain, was also carried out, if they could be related to the increase in temperature; however, there were no statistically significant differences in local temperatures between the participants who presented these manifestations and those who did not $(p>0.05)$.

\section{DISCUSSION}

According to the results of this study, conducted to assess the safety of the technique of intramuscular administration without aspiration, the adverse event presented most frequently was flushing, which is characterized by a local reaction possibly resulting from the inflammatory process resulting from the components of the immunobiological, such as aluminum hydroxide adjuvant, present in the composition of hepatitis $A$ vaccine (inactivated) and other inactivated vaccines, in order to enhance the immune response by inducing inflammation at the injection site ${ }^{(10)}$.

However, in many cases, the flushing was limited to the edges of the injection site and regressed spontaneously, with a maximum size of $0.50 \mathrm{~cm}$ on the first day after vaccination, with a possible relationship with the passage of the needle, which, in itself, causes minor injury and tissue irritation ${ }^{(9)}$. Size was smaller than the cases presented in the deltoid region after the first dose of the HPV vaccine in adolescents, with a maximum size of $1.2 \mathrm{~cm}$, but below $0.4 \mathrm{~cm}$ in most cases $^{(11)}$.

A study carried out from 2004 to 2013, in Brazil, in the population aged 60 or over, flushing occurred in $37.11 \%$ of cases and was related to vaccination with different immunobiological agents, an approximate percentage of this study, in which $44.6 \%$ of participants had flushed on the first day after vaccination, decreasing on the following days ${ }^{(12)}$. In children under 2 years of age, after the first dose of hepatitis A vaccine, $9.9 \%$ of the cases showed redness in this age group ${ }^{(13)}$. 
Injection site pain was the second most frequent local manifestation in this study, reported mainly on the first day after vaccination by $15.6 \%$ of participants. This percentage was similar to a study using the inactivated hepatitis $A$ vaccine in children and adolescents aged 12 months to 16 years, in which $13.4 \%$ of subjects had some type of pain in the days following vaccination $^{(13)}$. It was described in a systematic review regarding the immunogenicity and safety of the combined hepatitis $A$ and $B$ vaccine (inactivated) for adults, in which the most reported reaction was local pain ${ }^{(14)}$.

The local reactions expected for hepatitis A vaccine (inactivated) are pain, erythema or edema and induration, being mild and transient in most cases $^{(6)}$. Like this study, local manifestations are also the most reported for any vaccine, representing about $28 \%$ of the total of adverse events reported in the province of Cuba, highlighting pain, induration and signs of local inflammation for more than three days as the most frequent reactions ${ }^{(15)}$.

Other manifestations adjacent to the application region, evidenced less frequently in this study, were hematoma, muscle fatigue, paresthesia, cramps and leg pain, which are adverse events reported in the vaccination of children and adults against hepatitis $A$ and other vaccines ${ }^{(12-13)}$.

The cases of hematoma occurred homogeneously among people submitted to vaccination with or without aspiration, observed in only nine participants (5.8\%), an event that is potentially related to IM injections due to trauma to the wall of some blood capillary caused by passage of the needle, causing small local bleeding. To prevent it, soft tissue compression after injection is indicated ${ }^{(16)}$. In a study with participants from 1 to 15 years of age, $2.1 \%$ had this reaction after hepatitis A vaccine administration ${ }^{(13)}$.

Local adverse events occurred less frequently in IG (technique without aspiration) compared to CG (technique with aspiration), but without significant differences. Similar to the study carried out with young adults aged 19 to 24 years using the tetanus vaccine, to compare the technique of rapid injection ( 1 to 2 seconds), without performing aspiration with the standard technique of slow injection (5 to 10 seconds) with aspiration, in which CG (standard technique) also had more local reactions than IG and there were no statistically significant differences ${ }^{(2)}$.

The composition of the vaccine, due to the presence of the antigen or adjuvant (substance used to potentiate or modulate the response to the antigen), already has inherent potential to generate a local inflammatory reaction, in the lymphatic tissue and other clinical changes, which are expected and make part of the immune response. It also varies according to the specific characteristics of each immunobiological and producing laboratory ${ }^{(17)}$.

In a study carried out with adults aged 21 to 63 years using a thermographic image of individuals vaccinated against Influenza in the deltoid muscle, a positive correlation was found between flushing and temperature at the injection site 24 hours after vaccination $^{(18)}$. However, in the present study, no significant association was found between local pain and flushing with local temperature.

Local heat consists of one of the signs of inflammation, generated by the increase in blood flow in a given region, with the displacement of phagocytes and other components of the innate immune response in the recognition of a component not proper to the organism. Thus, it is an adverse reaction expected for most vaccines, whether or not accompanied by other cardinal signs of inflammation, such as flushing, edema, and pain ${ }^{(19)}$.

In the aforementioned study, participants with elevated injection site temperatures were classified in high reactors ( $37 \%$ of vaccinees), with an increase of more than $0.75^{\circ} \mathrm{C}$ in the local temperature on the application side 24 hours after vaccination; low reactors were those with variations below $0.25^{\circ} \mathrm{C}(29 \%$ of those vaccinated); people with temperature variation between $0.25^{\circ} \mathrm{C}$ and $0.75^{\circ} \mathrm{C}$ were classified as intermediate reactors ${ }^{(18)}$. However, it was not possible to apply this classification in the present study, as participants' local temperatures were not measured before vaccination.

Although a significant difference was found in the temperature of the vaccine application site on the second day after vaccination, with a mean of $0.76^{\circ} \mathrm{C}$ higher in IG compared to CG; but given the impossibility of comparing with pre-vaccination local values, it is allowed to infer only that the temperature rise in the group submitted to the technique without aspiration did not have repercussions in the occurrence of local adverse events, such as pain and redness.

Regarding the systemic manifestations after vaccination, headache was reported by $9.6 \%$ of participants in the 72 hours after vaccination, which may be associated with vaccination or other factors. In a study with elderly people, $5.64 \%$ of the elderly reported headache related to the administration of different vaccines ${ }^{(12)}$. In a systematic review with studies that analyzed adverse events with the inactivated hepatitis $A$ and $B$ vaccine, the percentages of headache occurrence ranged from $2.1 \%$ to $38.7 \%$ in studies with adults $^{(14)}$. In a study with inactivated hepatitis A vaccine, $8.7 \%$ of participants aged 2 to 11 years reported headache, while $19.8 \%$ of individuals aged 12 to 15 years reported the symptom within seven days after vaccination ${ }^{(13)}$.

The second most frequent systemic manifestation was fatigue, reported by $4 \%$ of participants, a rate close to the percentage informed by the CRIE Manual, Ministry of Health, in which fever and fatigue occur in less than $5 \%$ of those vaccinated, being rare the cases of anaphylaxis(6).

The manifestations presented, such as nausea, diarrhea (gastrointestinal disorder), colic (abdominal pain), dizziness and body pain (myalgia), were also reported in other studies associated with vaccination and occurred less frequently in this study ${ }^{(12-13)}$. Sleep disorders (drowsiness) were reported by $1.4 \%$ of participants in the 24 hours after vaccination, and, according to the Ministry of Health's Epidemiological Surveillance of Adverse Events Following Immunization, it is an adverse event related to some vaccines within 48 hours post-vaccination ${ }^{(9)}$.

Other systemic manifestations reported in the study were chills and sore throats. Shivering is characterized as a tremor related to involuntary muscle contractions and was associated with other symptoms in this participant (cramp and myalgia). In a study conducted with Meningococcal ACWY vaccine in adults aged 18 to 45 years, $5 \%$ of participants reported chills ${ }^{(20)}$.

Moreover, the symptom referred to as sore throat, presented by only one participant, was related to other manifestations (headache and myalgia) in this individual. It is described as an expected adverse event in the hepatitis A vaccine package (inactivated) ${ }^{(21)}$; however, there is a possibility of being associated with an inflammatory or infectious condition that does not result from vaccination. 
Systemic manifestations regressed over participants' 72-hour follow-up and there were no serious adverse events, as in a study conducted with inactivated hepatitis $A$ vaccine in adolescents, in which the majority of AEFIs were classified as mild to moderate in intensity and resolved within five days after vaccination ${ }^{(22)}$, demonstrating that hepatitis A vaccine (inactivated) is safe, with mild and well tolerated local or systemic adverse events, in addition to being highly immunogenic, it is estimated that more than $95 \%$ of vaccinated individuals will remain seropositive for more than 20 years ${ }^{(23)}$.

It is known that one of the reasons given for performing IM aspiration is the fear of intravenous (IV) injection of liquid, in order to cause some harm to individuals vaccinated by inadvertent IV administration. However, the angle indicated for IM $\left(90^{\circ}\right)$ will hardly allow the insertion of the needle bevel in the light of a vein, because, in addition to the lack of large caliber vessels in the regions indicated for vaccination, EV administration requires a smaller needle insertion angle $\left(10^{\circ} \text { to } 20^{\circ}\right)^{(24-25)}$.

Literature that recommended aspiration is old and describes the need to retract the syringe plunger backwards from 5 to 10 seconds in order to create enough negative pressure in the tissue for blood to flow into the syringe if the needle bevel is in a vessel low flow blood ${ }^{(26)}$. However, in nursing practice, it is noticed that the technique, possibly, is not performed according to this orientation, as well as its need for performance has not been studied.

Thus, the results of this study indicate that the IM injection technique without aspiration in the VG region is similar to the conventional technique with aspiration in relation to the adverse events presented after hepatitis $A$ vaccine administration (inactivated); more evidence is shown regarding the safety of non-aspiration in the context of IM vaccination.

\section{Study limitations}

Local and contralateral temperature measurements were not carried out before vaccination, which would allow individuals to be classified as low, intermediate or high reactors according to post-vaccination temperatures and would enable a better understanding of this parameter in this study.

\section{Contributions to nursing}

The results of this research contribute to nursing practice in the immunization room, instrumentalizing professionals in implementing the IM technique without aspiration, as it offers more evidence regarding the safety of this technique in another region of application (VG), since others conducted clinical trials investigated non-aspirated injection into the deltoid and vastus lateralis muscles of the thigh.

\section{CONCLUSIONS}

It was observed that the IM vaccination technique without aspiration before injection is safe for AEFI against hepatitis $A$ in the VG region, compared to the conventional technique with aspiration; The frequency of local and systemic adverse events was similar between the intervention and control groups as well as there were no serious adverse events in any of the groups. Thus, there is more evidence to support the practice of nursing professionals in vaccination services in the implementation of the studied technique, considering its safety in this injection site (VG) and the agility provided to the procedure by reducing the time of discomfort to which individuals are subjected.

\section{FUNDING}

This study was sponsored by the Ministry of Health, with the supply of immunobiological agents, and financed by the Brazilian National Council for Scientific and Technological Development (CNPq - Conselho Nacional de Desenvolvimento Científico e Tecnológico)/Ministry of Science, Technology, Innovations and Communications (MCTIC - Ministério da Ciência, Tecnologia, Inovações e Comunicações), Universal Call 28/2018, for other expenses.

\section{REFERENCES}

1. Taddio A, Mcmurtry CM, Shah V, Riddell RP, Chambers $C T$, Noel M, et al. Reducing pain during vaccine injections: clinical practice guidelines. CMAJ. 2015;187(13):975-82. https://doi.org/10.1503/cmaj.150391

2. Gol I. The effect of the rapid injection technique without aspiration on pain level in intramuscular vaccination: a single-blind randomizedcontrolled trial. Ann Med Res. 2020;27(1):319-25. https://doi.org/10.5455/annalsmedres.2019.10.602

3. Brown AL, Sperandio M, Turssi CP, Leite RMA, Berton VF, Succi RM, et al. [Vaccine confidence and hesitancy in Brazil]. Cad Saude Publica. 2018;34(9):e00011618. https://doi.org/10.1590/0102-311X00011618 Portuguese.

4. Dey A, Wang H, Quinn H, Hiam R, Wood N, Beard F, et al. Surveillance of adverse events following immunisation in Australia annual report, 2017. Commun Dis Intel. 2019;43. https://doi.org/10.33321/cdi.2019.43.29

5. Sales MCV, Araújo MCB, Almeida CAPL, Moura LKB. Post-vaccination adverse events: integrative review. Rev Enferm UFPE. 2017;11(Supl.10):4243-53. https://doi.org/10.5205/reuol.10712-95194-3-SM.1110sup201730

6. Ministério da Saúde (BR). Reference centers manual for special immunobiologicals. Brasília: Ministério da Saúde; 2019 [cited 2020 Aug 8 ]. 174 p. Available from: http://bvsms.saude.gov.br/bvs/publicacoes/manual_centros_imunobiologicos_especiais_5ed.pdf

7. Göl I, Özsoy SA. Effects of rapid vaccine injection without aspiration and applying manual pressure before vaccination on pain and crying time in infants. Worldviews Evid Based Nurs. 2017;14(2):154-62. https://doi.org/10.1111/wvn.12206

8. Meneses AS, Marques IR. A proposal for a geometrical delimitation model for ventro-gluteal injection. Rev Bras Enferm. $2007 ; 60(5): 552-8$. https://doi.org/10.1590/s0034-71672007000500013 
9. Ministério da Saúde (BR). [Epidemiological surveillance manual of adverse events after vaccination]. 2014 [cited 2020 Sep 13 ]. 250 p. Available from: http://bvsms.saude.gov.br/bvs/publicacoes/manual_vigilancia_epidemiologica_eventos_adversos_pos_vacinacao.pdf Portuguese.

10. He P, Zou Y, Hu Z. Advances in aluminum hydroxide-based adjuvant research and its mechanism. Hum Vaccin Immunother. 2015;11(2):47788. https://doi.org/10.1080/21645515.2014.1004026

11. Petousis-Harris $\mathrm{H}$, Poole T, Stewart J, Turner N, Goodyear-Smith F, Coster G, et al. An investigation of three injections techniques in reducing local injection pain with a human papillomavirus vaccine: a randomized trial. Vaccine. 2013;31(8):1157-62. https://doi.org/10.1016/j. vaccine.2012.12.064

12. Linheira-Bisetto LH, Ciosak SI, Cordeiro TLR, Boing MS. Adverse events following immunization of the elderly. Cogitare Enferm [Internet]. 2016 [cited 2020 Sep 19];21(4):01-10. Available from: http://docs.bvsalud.org/biblioref/2016/12/827175/45682-190058-1-pb.pdf

13. Bravo C, Mege L, Vigne C, Thollot Y. Clinical experience with the inactivated hepatitis A vaccine, Avaxim $80 U$ Pediatric. Expert Rev Vaccines. 2019;18(3):209-23. https://doi.org/10.1080/14760584.2019.1580578

14. Bakker M, Bunge EM, Marano C, Ridder M, De Moerlooze L. Immunogenicity, effectiveness and safety of combined hepatitis A and B vaccine: a systematic literature review. Expert Rev Vaccines. 2016;15(7):829-51. https://doi.org/10.1586/14760584.2016.1150182

15. Osoria OC, Almeida MAP, Aguilar MEB. [Adverse events associated with vaccination in children under 2 years of age. Granma Province. 2014-2018]. Multimed (Granma) [Internet]. 2019 [cited 2020 May 11];23(5). Available from: http://scielo.sld.cu/pdf/mmed/v23n5/1028-4818mmed-23-05-940.pdf Spanish.

16. Kim SG, Shim KS, Lee DW, Kim EJ, Lee SG, Lee JH, et al. Intramuscular hematoma with motor weakness after trigger point injection: a case report. Medicine (Baltimore). 2017;96(39):e8135. https://doi.org/10.1097/MD.0000000000008135

17. Baldrick P. Dose site reactions and related findings after vaccine administration in safety studies. J Appl Toxicol. 2016;36(8):980-90. https:// doi.org/10.1002/jat.3314

18. Hoffmann A, Dumke C, Hanschmann KO, Wicker S. Local thermal reaction after influenza vaccination: quantification by infrared imaging and biometric considerations. Vaccine. 2018;36(20):2783-7. https://doi.org/10.1016/j.vaccine.2018.04.001

19. Majno G, Joris I. Cells, tissues, and disease: principles of general pathology. New York: Oxford University Press; 2004.1040 p.

20. Chen WH, Neuzil KM, Boyce CR, Pasetti MF, Reymann MK, Martellet L, et al. Safety and immunogenicity of a pentavalent meningococcal conjugate vaccine containing serogroups $A, C, Y, W$, and $X$ in healthy adults: a phase 1, single-centre, double-blind, randomised, controlled study. Lancet Infect Dis. 2018;18(10):1088-96. https://doi.org/10.1016/S1473-3099(18)30400-6

21. Lemos FC. [VAQTA: hepatitis A adsorbed vaccine (inactivated)]. Campinas: Merck Sharp \& Dohme Farmacêutica Ltda; 2015 [cited 2018 Jul 16]. 9 p. Available from: http://200.199.142.163:8002/FOTOS_TRATADAS_SITE_14-03-2016/bulas/42308.pdf Portuguese.

22. Yoon SH, Kim HW, Ahn JG, Kim IT, Kim JH, Kong KA, et al. Reappraisal of the immunogenicity and safety of three Hepatitis A vaccines in adolescents. J Korean Med Sci. 2016;31(1):73-9. https://doi.org/10.3346/jkms.2016.31.1.73

23. Hens N, Ghebretinsae AH, Hardt K, Van Damme P, Van Herck K. Model based estimates of long-term persistence of inactivated hepatitis A vaccine-induced antibodies in adults. Vaccine. 2014;32(13):1507-13. https://doi.org/10.1016/j.vaccine.2013.10.088

24. Hamborsky J, Kroger A, Wolfe S, (Orgs.). Epidemiology and prevention of vaccine-preventable diseases [Internet]. Washington D.C.: Public Health Foundation, 2015 [cited 2020 Apr 1]. 376 p. Available from: https://www.cdc.gov/vaccines/pubs/pinkbook/index.html

25. Yang L, Yin A, Liu W. Variation of flow rate and angle of injected venous needle on influencing intimal hyperplasia at the venous anastomosis of the hemodialysis graft. Australas Phys Eng Sci Med. 2017;40(1):239-248. https://doi.org/10.1007/s13246-017-0526-6

26. Thomas CM, Mraz M, Rajcan L. Blood aspiration during IM injection. Clin Nurs Res. 2016;25(5):549-59. https://doi. org/10.1177/1054773815575074 